\title{
Role of krill versus bottom-up factors in controlling phytoplankton biomass in the northern Antarctic waters of South Georgia
}

\author{
M. J. Whitehouse ${ }^{1, *}$, A. Atkinson ${ }^{1}$, P. Ward ${ }^{1}$, R. E. Korb ${ }^{1}$, P. Rothery ${ }^{2}$, S. Fielding ${ }^{1}$ \\ ${ }^{1}$ British Antarctic Survey, Natural Environmental Research Council, High Cross, Madingley Road, Cambridge CB3 0ET, UK \\ ${ }^{2}$ Centre for Ecology and Hydrology, Natural Environmental Research Council, Monks Wood, Abbots Ripton, \\ Huntingdon PE28 2LS, UK
}

\begin{abstract}
The extent to which Antarctic phytoplankton stocks are controlled by 'bottom-up' and/or 'top-down' factors is highly variable. Here we consider data collected at South Georgia during 3 summer surveys that recorded substantial hydrographic variability. A suite of bottom-up and top-down controlling factors were measured simultaneously at the mesoscale. Sea surface temperature varied by $>2{ }^{\circ} \mathrm{C}$, macronutrients ranged from near-winter concentrations to near-depleted, while mean densities of a major grazer, krill Euphausia superba, varied between near-zero and $>400 \mathrm{~g}$ wet mass $\mathrm{m}^{-2}$. A general linear model was used to identify the main factors implicated in the observed differences in phytoplankton biomass. Despite east-to-west and on- to off-shelf temperature gradients, temperature per se was not implicated in phytoplankton variability. Also, while there was an abundance of $\mathrm{NO}_{3}-\mathrm{N}$ in surface waters, $\mathrm{NH}_{4}-\mathrm{N}$ was the key nutrient throughout. A domed relationship between phytoplankton and krill peaked between 2 and $4 \mathrm{mg}$ chlorophyll $\mathrm{a} \mathrm{m}^{-3}$ and 6 and $30 \mathrm{~g}$ krill $\mathrm{m}^{-2}$. The positive side of this dome was represented by the west off-shelf region downstream of South Georgia. Here, an ample supply of micro- and macronutrients promoted high primary production, and low densities of krill presumably had little grazing effect. This positive relationship between krill and phytoplankton biomasses was interpreted as krill accumulating in areas of good feeding conditions. The negative side of the dome was typified by the east off-shelf region, where macronutrients remained high, primary production rates were low, and krill densities were very high. The grazing rates calculated here suggested that krill affect their food stocks severely, and the negative krill-phytoplankton relationship in this region may reflect locally high krill densities driving down their food supply.
\end{abstract}

KEY WORDS: Antarctic phytoplankton $\cdot$ Macronutrients $\cdot \mathrm{NH}_{4} \cdot$ Temperature $\cdot$ Grazing effect

Resale or republication not permitted without written consent of the publisher

\section{INTRODUCTION}

The extent to which Antarctic phytoplankton stocks are controlled by 'bottom-up' physical and chemical factors or by 'top-down' grazing has been debated for decades (e.g. Hardy \& Gunther 1935, Hart 1942, Chisholm \& Morel 1991, Atkinson et al. 2001, Ward et al. 2002, 2005, Smetacek et al. 2004, Smith \& Lancelot 2004, Harris 2005, Murphy et al. 2007). To date, bottom-up factors have probably received the most attention, doubtless because it is easier to measure temperature, mixed layer depths and nutrients than to quantify grazing by a plethora of patchily distributed grazer species. Furthermore, the simultaneous measurement of bottom-up and top-down control is fraught with difficulty (Martin 2003), especially in the Southern Ocean where sampling opportunities are infrequent.

Iron enrichment experiments have demonstrated unequivocally that, over large parts of the Southern Ocean, phytoplankton are under bottom-up control due to a chronic lack of iron in surface waters (e.g. Boyd et al. 2007). Smith \& Lancelot (2004) argued further that bottom-up control was strongest for the large, bloom-forming diatoms, since their large size offered a 
refuge from predation from the protozoans that generally dominate the grazer assemblage (Calbet \& Landry 2004). In contrast, the meso- and macroplankton that can deal with the large or chain-forming diatoms have longer generation times, and thus cannot increase their populations fast enough to keep a bloom in check (Smetacek et al. 2004).

While these generalities may hold, local or regional exceptions may exist. One that has received attention is the potential for Antarctic krill Euphausia superba (hereafter krill) to substantially reduce their food supply. Krill are important grazers in large, productive, mid-latitude subsystems of the Southern Ocean, often with 'key species' status due to their large biomass, high energy demands and prominent role in predator species (Atkinson et al. 2001). While the production and grazing effect of krill is minor compared to protozoans and mesozooplankton over the Southern Ocean as a whole (Voronina 1998, Pakhomov et al. 2002, Shreeve et al. 2005), their very uneven distribution is key, as compared to the other grazers. Thus, in areas where krill swarms are locally numerous they have often been suggested to have a major grazing effect, with biogeochemical ramifications (reviewed by Smetacek et al. 2004). However, much of the evidence for this has been anecdotal, and only rarely has it been possible to monitor suitable indices of phytoplankton, krill, and the potential bottom-up control factors simultaneously.

Where such studies have been conducted (e.g. Hardy \& Gunther 1935, Weber \& El-Sayed 1985, Weber et al. 1986, Lawson et al. 2008), they have arrived at a variety of conclusions. Both positive and negative relationships between phytoplankton and krill have been found, with the former interpreted as the krill aggregating in good feeding grounds and the latter implying that krill have grazed down their food (Weber et al. 1986). The sign of this relationship has been suggested to depend partly on the scale of analysis, and various positive, negative and dome-shaped relationships have been found across a wide range of scales (e.g. Weber et al. 1986, Atkinson et al. 2008, Lawson et al. 2008).

In this study, we selected South Georgia as a study site to examine the control on phytoplankton via bottom-up factors and krill grazing. While such productivity hotspots comprise only a fraction of the Southern Ocean, they are important biogeochemically in terms of total carbon flows and for commercially important food webs (Atkinson et al. 2001, Schlitzer 2002, Ducklow et al. 2006). South Georgia is also particularly well suited to such a study. First, during summer it is probably iron replete (Holeton et al. 2005, Korb et al. 2008, Whitehouse et al. 2008), making it easier to consistently assess the effects of other bottom-up factors (e.g. macronutrients, temperature, mixed-layer depths) across multiple cruises. Second, there is good background knowledge of this area, with extensive datasets on physics, nutrients, phytoplankton and krill (e.g. Whitehouse et al. 1996, Brierley et al. 1997, Trathan et al. 2003, Korb et al. 2004, Meredith et al. 2005).

We used data from 3 summer surveys to the north of South Georgia to examine the controls on phytoplankton biomass. The surveys were conducted in consecutive years during which there was substantial hydrographic variability within the region (Meredith et al. 2005). We examined the interactions observable at the mesoscale $(10 \mathrm{~s}$ of $\mathrm{km})$ by means of regressions, generalised additive models (GAMs) and general linear models (GLMs). These in effect use the variation in bottom-up factors and at the mesoscale krill biomass as a kind of 'natural experiment' to identify the main factors implicated in the observed differences in phytoplankton biomass.

\section{MATERIALS AND METHODS}

Survey methods. Underway oceanographic and bioacoustic data were collected simultaneously within 2 survey grids: 1 to the northwest and another to the northeast of South Georgia (Fig. 1). Survey grids comprised $10 \times 80 \mathrm{~km}$ long transects, roughly perpendicular to the island's shelf-break. While surveying, the nominal ship speed was 10 knots. We surveyed 2 transects $\mathrm{d}^{-1}$, and each survey grid took $5 \mathrm{~d}$ to complete. Data were collected during 3 consecutive years: 1996/97 (cruise JR17, December 1996 and January 1997); 1997/98 (cruise JR28, January and February 1998); 1998/99 (cruise JR38, December 1998 and January 1999). In addition, on- and off-shelf CTD casts were made during most survey days within each surveyed region.

Krill acoustics data. The transects were surveyed primarily to acoustically estimate the biomass of krill, as part of a long-term monitoring programme (Brierley et al. 1999, Murphy et al. 2007). Acoustic data were collected solely during daylight hours to reduce the possibility of bias due to diurnal migration (Demer \& Hewitt 1995) or change in target orientation (Everson 1982). Volume backscattering strength $\left(\mathrm{S}_{\mathrm{v} i} \mathrm{~dB}\right.$ re $\left.1 \mathrm{~m}^{-1}\right)$ was collected using a Simrad EK500 $(38,120 \mathrm{kHz})$ calibrated using the standard sphere method (Foote et al. 1987). The ping rate varied between 1.5 and $2.5 \mathrm{~s}$, but was constant within a survey.

All acoustic data were processed using Echoview software (ver. 4.20.59.8698); relevant values for the speed of sound and absorption coefficients were input (derived from concurrent CTD data); surface noise, false bottom echoes and interference were identified and removed; and time varied gain amplified background noise was subtracted (Watkins \& Brierley 

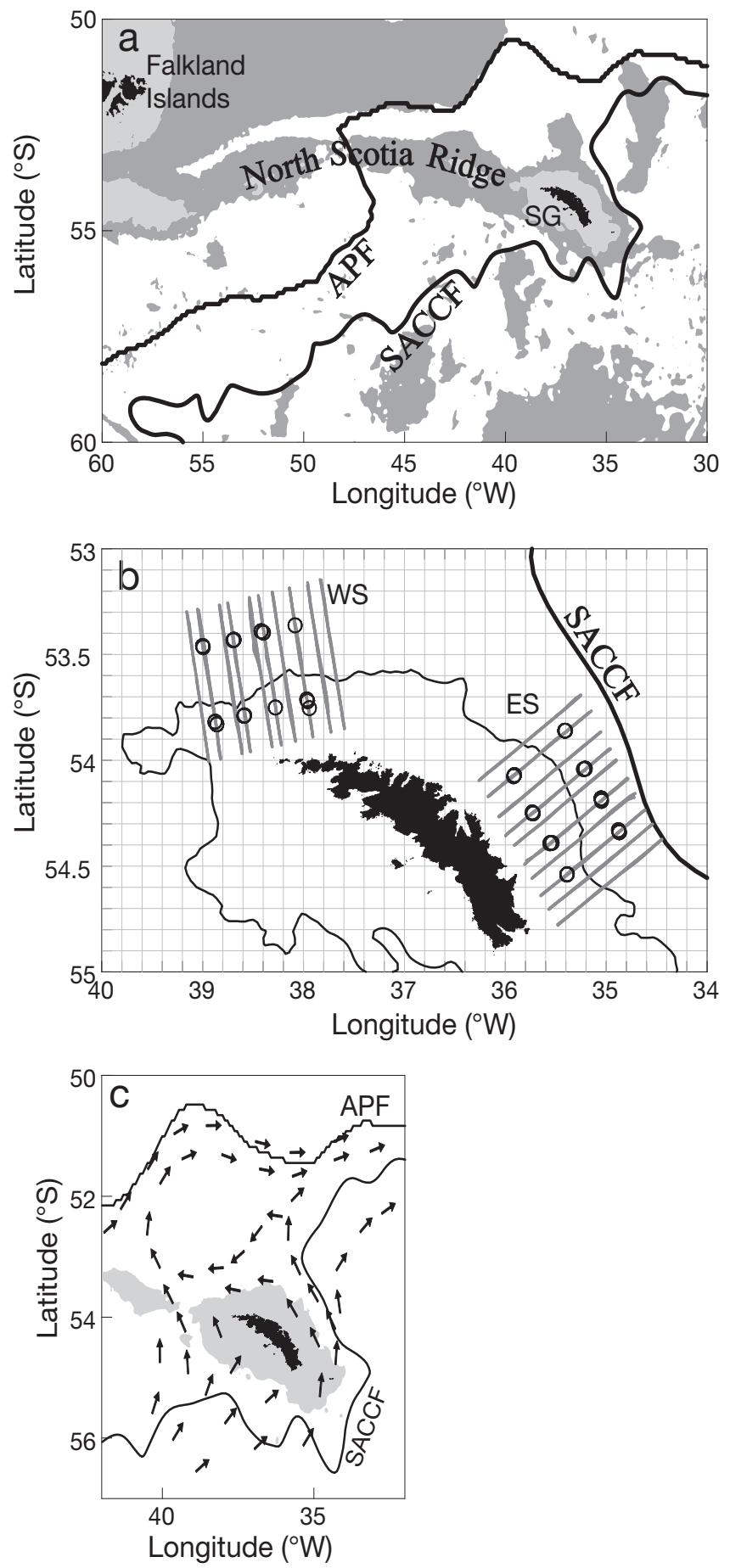

Fig. 1. (a) Location of South Georgia (SG) relative to the mean positions of the Antarctic Polar Front (APF) and the Southern Antarctic Circumpolar Current Front (SACCF). Pale and dark grey shading are delineated by the 1000 and the $3000 \mathrm{~m}$ isobaths, respectively. (b) West (WS) and east (ES) survey transects along with CTD station locations (o) in relation to South Georgia, the $1000 \mathrm{~m}$ isobath, the mean position of the SACCF and the $0.1^{\circ}$ latitude by $0.2^{\circ}$ longitude grid by which samples were grouped. (c) General current flow in relation to South Georgia, the $1000 \mathrm{~m}$ isobath, and the mean positions of the APF and the SACCF (from Korb et al. 2004)
1996). Cleaned data for each frequency were averaged into $5 \mathrm{~m}$ (vertical) by $500 \mathrm{~m}$ (horizontal) integration cells and imported into Matlab where any further manipulation or analysis was undertaken.

$\mathrm{S}_{\mathrm{v}}$ at $120 \mathrm{kHz}\left(\mathrm{S}_{\mathrm{v} 120 \mathrm{kHz}}\right)$ were apportioned to krill using a variable $\mathrm{dB}$ window differencing identification technique using the 120 and $38 \mathrm{kHz}\left(\mathrm{S}_{\mathrm{v} 120-38}\right)$ frequencies (Method 2, Reiss et al. 2008). Window ranges for different size ranges of krill (identified from the net samples in each survey region in each year) were taken from the current agreed Commission for the Conservation of Antarctic Marine Living Resources (CCAMLR) protocol for krill $\mathrm{B}_{0}$ assessment (CCAMLR 2009).

The $\mathrm{S}_{\mathrm{v} 120 \mathrm{kHz}}$ attributable to krill were integrated from $10 \mathrm{~m}$ below the surface to either a maximum of $250 \mathrm{~m}$ or $2 \mathrm{~m}$ above the seabed, resulting in nautical area scattering coefficient (NASC; $\mathrm{m}^{2}$ nautical mile ${ }^{-2}$ ) values. NASC were converted to krill biomass $\left(\mathrm{g} \mathrm{m}^{-2}\right)$ using the simplified stochastic distorted-wave Born approximation (SDWBA) target strength model, which was applied using fixed values for orientation $(11,4)$ and material properties based on those calculated/inferred for the CCAMLR synoptic survey in the Scotia Sea region at the same time of year as the present study (Conti \& Demer 2006, CCAMLR 2009), and weighted mean masses per individual, using the mass to length relationship also collected during the CCAMLR Scotia Sea survey (Hewitt et al. 2004).

Oceanographic, nutrient and chlorophyll data. The underway sample source for chlorophyll (chl a) and nutrient samples was the ship's non-toxic supply at $\sim 7 \mathrm{~m}$ below sea surface. A Turner Model 10 throughflow fluorometer was used to measure in vivo fluorescence, while discrete samples, taken hourly from the same source, were extracted with acetone and analysed with a Sequoia-Turner Model 112 benchtop fluorometer. The benchtop fluorometer was calibrated against a standard prepared from chl a extracted from the cyanobacterium Anacystis nidulans (Sigma Chemicals; Parsons et al. 1984). Underway chl a was estimated from in vivo fluorescence with a model that used simultaneous measurements of incident photosynthetically active radiation and the high frequency discrete samples to allow for anomalies such as those caused by light-quenching and variations in phytoplankton community composition. The fitted model accounted for $>96 \%$ of the variance in the underway measurements (A. W. A. Murray \& J. Priddle, British Antarctic Survey [BAS], unpubl. report). Macronutrients were monitored continuously by feeding a filtered sample stream to a Technicon autoanalyser (Whitehouse 1997, Woodward et al. 1999). The same analytical methods were used to measure chl a and macronutrients in discrete CTD water bottle samples. Underway temperature was measured with a sensor at 
the non-toxic supply's intake on the ship's hull, and was periodically checked against CTD measurements.

Calculation of nutrient depletion. To enable regional comparisons to be made, nutrient deficits were calculated by subtracting measured surface values from an estimated generic pre-bloom concentration for South Georgia of 35, 2.1 and $30 \mathrm{mmol} \mathrm{m}^{-3}$ for $\mathrm{Si}(\mathrm{OH})_{4}$, $\mathrm{PO}_{4}$ and $\mathrm{NO}_{3}$, respectively (Whitehouse et al. 1996, 2000, 2008, BAS unpubl. data). These calculated deficits should be regarded only as an index of nutrient use, as upwelling and re-supply doubtless occur to some extent at the island's shelf-break. To identify preferential nutrient use, e.g. greater nitrate utilisation, we then calculated ratios of nutrient deficits between pairs of nutrients.

Scale of data analysis. The underway data were collected at various frequencies: once per minute for temperature and chl $a$, once per $10 \mathrm{~s}$ for macronutrients, while acoustic records were averaged into $0.5 \mathrm{~km}$ lengths of transect. Therefore, a common scale for all of the data needed to be ascertained to allow further analysis, with the finest data resolution imposed by the acoustic measurements: $0.5 \mathrm{~km}$ section of transect. Each survey grid took $5 \mathrm{~d}$ to complete, and transects were spaced $\sim 7$ to $10 \mathrm{~km}$ apart. Current velocities to the north of South Georgia (particularly off-shelf) can be as high as $50 \mathrm{~cm} \mathrm{~s}^{-1}$ (Brandon et al. 2000, Meredith et al. 2003a,b, Whitehouse et al. 2008), so water could potentially be transported across a survey grid in $\sim 2 \mathrm{~d}$. Given the high current velocities, passive nature of phytoplankton and nutrients in contrast with mobile krill, and the heavily skewed and aggregated krill distribution we found, the finest data resolution was inappropriate to resolve relationships that may have resulted through advection. Instead, a coarser scale was required. Given the influence of physical processes (e.g. Huntley \& Niiler 1995) on the distribution of phytoplankton, krill, and nutrients, we were guided by the horizontal scale of eddies as quantified by internal Rossby radius, which is $\sim 10 \mathrm{~km}$ at the latitude of South Georgia (Houry et al. 1987). With transects spaced $\sim 7$ to $10 \mathrm{~km}$ apart, this is the finest resolution we could use that might allow for effects brought about by advection downstream. A $0.1^{\circ}$ latitude by $0.2^{\circ}$ longitude grid around South Georgia conveniently produces a cell size of approximately $11 \times$ $13 \mathrm{~km}$, so we made our comparisons at this scale with mean values calculated for each grid cell (Fig. 1b).

We treated the west and east surveys separately for many of our comparisons, since their conditions vary substantially (e.g. Brierley et al. 1999, Korb \& Whitehouse 2004, Meredith et al. 2005). For the same reason, we divided the surveys into shelf $(<1000 \mathrm{~m})$ and oceanic $(>1000 \mathrm{~m})$ sub-regions. Most of the island's shelf is $<500 \mathrm{~m}$ depth, but the $1000 \mathrm{~m}$ isobath provides a much better delineation of the shelf break.
Data analysis was carried out with analyses of variance (ANOVAs), GAMs and GLMs in the Minitab program. The degrees of freedom of the fitted GAMs were chosen by cross-validation, i.e. minimising the sums of squares of deviations from the fitted values excluding 1 data point at a time.

To further elucidate inter- and intra-survey box differences, longitude was also included as an independent variable in the GLMs, despite the different orientation of the 2 transect grids. Given the variability in the predominantly east-to-west current flow and the counterclockwise rotation of 'north-south' Antarctic Circumpolar Current (ACC) characteristics to the north of South Georgia, we considered a simple unweighted east-west measurement to be a suitable spatial factor.

\section{RESULTS}

\section{Surface data compared to the top $50 \mathrm{~m}$ of the water column}

As our only sample source during underway surveying was the ship's non-toxic supply $(\sim 7 \mathrm{~m}$ below sea surface) and primary production measurements would usually be made over at least the euphotic layer, we needed to assess how representative our surface temperature and concentrations of chl $a$ and macronutrients were of the water column below. We examined the relationship between mean surface ( 0 to $7 \mathrm{~m}$ ) CTDderived chl $a$, temperature and nutrient data and those averaged over 0 to $50 \mathrm{~m}$ at the CTD stations within the surveyed areas (Table 1). Regressions between all parameters were highly significant $(\mathrm{p}<0.001)$ with $\mathrm{R}^{2}$ values $\geq 87 \%$. This relationship concurs with previous measurements in this area (see Gilpin et al. 2002, Korb et al. 2004, Whitehouse et al. 2008) in showing a good correlation between surface data and those collected within the top $50 \mathrm{~m}$ of the water column.

Table 1. Relationship between mean surface (0 to $7 \mathrm{~m})$ CTDderived chl $a$, temperature and nutrient data with those averaged over 0 to $50 \mathrm{~m}$. All available data from the 3 cruises were used, and station localities are indicated in Fig. 1b. Surface values $=x+(y \times$ near-surface values $)$, and all regressions were highly significant $(\mathrm{p}<0.001)$

\begin{tabular}{|lcrrl|}
\hline Parameter & $\mathrm{n}$ & $\mathrm{R}^{2}$ & \multicolumn{1}{c|}{$x$} & \multicolumn{1}{c|}{$y$} \\
\hline Log $_{10}$ chl a & 16 & 96 & 0.0328 & 1.087 \\
Temperature & 44 & 88 & 0.2891 & 0.9966 \\
$\mathrm{SiOH}_{4}$ & 29 & 98 & -0.1938 & 0.9848 \\
$\mathrm{PO}_{4}$ & 31 & 94 & 0.0005 & 0.9748 \\
$\mathrm{NO}_{3}$ & 31 & 96 & -0.0541 & 0.9868 \\
$\mathrm{NH}_{4}$ & 31 & 87 & -0.1245 & 0.9687 \\
\hline
\end{tabular}




\section{Spatial and temporal variability}

All parameters showed variability from year to year, from west to east, and from on-shelf to off-shelf. In the first 2 surveys, chl a concentrations were significantly higher in the west than the east $(p<0.001)$ but differed less during the third survey (Fig. 2a). They differed less from on-shelf to off-shelf waters than they did either between west and east or between years. Highest values (mean $\pm \mathrm{SD}: 6 \pm 2.3 \mathrm{mg} \mathrm{m}^{-3}$ ) were found in west off-shelf waters during $1996 / 97$ and the lowest $(0.7 \pm$ $0.14 \mathrm{mg} \mathrm{m}^{-3}$ ) in east on-shelf waters during 1997/98.

In the first 2 surveys, krill densities were significantly higher in the east but were more uniformly distributed during 1998/99 (Fig. 2b). Within survey boxes, densities were significantly higher on-shelf during the first 2 surveys but again were more uniformly distributed during 1998/99. Highest values (409 $\pm 416 \mathrm{~g}$ wet mass $\mathrm{m}^{-2}$ ) were found in east on-shelf waters during 1997/98 and the lowest $\left(5.1 \pm 7.8 \mathrm{~g} \mathrm{~m}^{-2}\right)$ in west off-shelf waters during the same season.

Ocean temperature within the sub-regions varied by $\sim 2^{\circ} \mathrm{C}$ (mean 1.5 to $3.5^{\circ} \mathrm{C}$ ) over the 3 surveys (Fig. $2 \mathrm{c}$ ). During the 2 earlier surveys, temperatures were significantly lower in the east $(\mathrm{p}<0.001)$ but were more uniform during 1998/99. In 1996/97, the greatest on- to
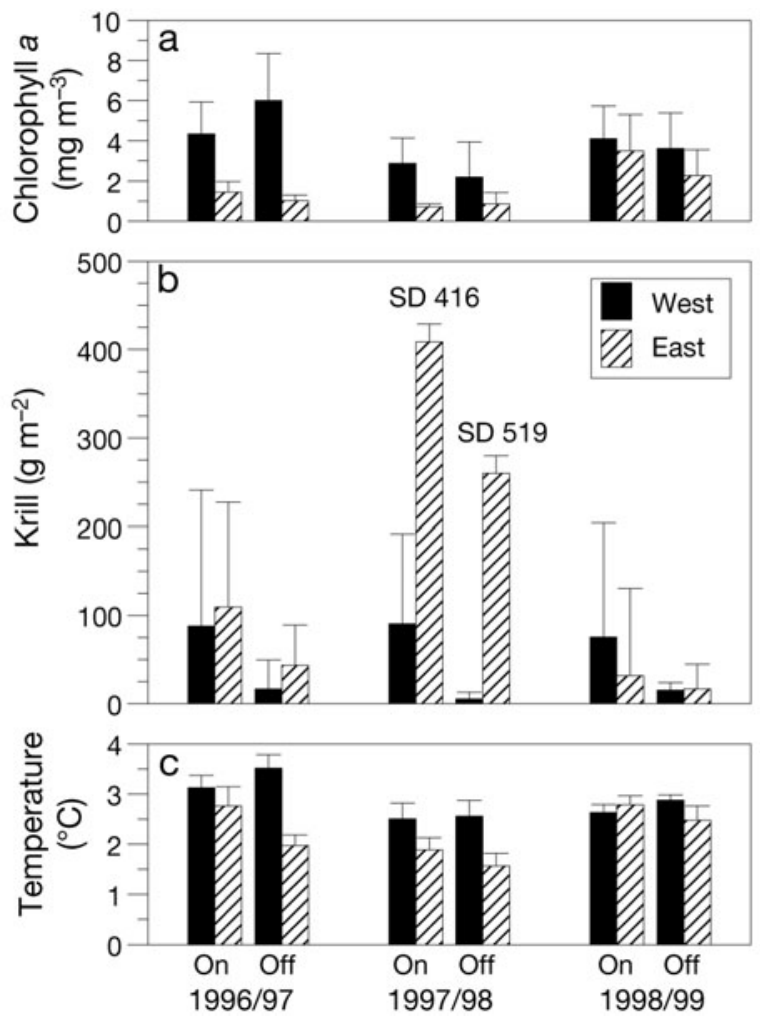

off-shelf temperature difference $\left(\sim 0.95^{\circ} \mathrm{C}\right)$ was found in the east, while overall, the lowest temperatures were encountered during 1997/98.

$\mathrm{Si}(\mathrm{OH})_{4}$ concentrations were particularly high during 1997/98 (>20 $\mathrm{mmol} \mathrm{m}^{-3}$ in most regions), while the lowest were found in 1998/99 $\left(<10 \mathrm{mmol} \mathrm{m}^{-3}\right.$ in most regions; Fig. 2d). In 1996/97, particularly low values $\left(5.2 \pm 6.2 \mathrm{mmol} \mathrm{m}^{-3}\right)$ in west off-shelf waters contrasted with all other regions where mean concentrations were $>17 \mathrm{mmol} \mathrm{m}^{-3}$. $\mathrm{PO}_{4}$ and $\mathrm{NO}_{3}$ concentrations were closely related, and the lowest values were always found in the west (Fig. 2e,f). During 1997/98, particularly low values $\left(\sim 0.5\right.$ and $12 \mathrm{mmol} \mathrm{m}^{-3}$, respectively) were found in marked contrast to ambient $\mathrm{Si}(\mathrm{OH})_{4}$ concentrations. These lowest ambient $\mathrm{NO}_{3}$ values in the west were coincidental with high $\mathrm{NO}_{3}: \mathrm{PO}_{4}$ deficit ratios of $\sim 16: 1$ and low $\mathrm{Si}(\mathrm{OH})_{4}: \mathrm{NO}_{3}$ deficit ratios of $\sim 1$ to 2 (Fig. 3). Overall, $\mathrm{NH}_{4}$ concentrations were highest $\left(>0.5 \mathrm{mmol} \mathrm{m}^{-3}\right.$ in most regions) during the 1997/98 survey with lower values (<0.5 mmol $\mathrm{m}^{-3}$ in most regions) evident during 1998/99 (Fig. 2g). During 1996/97, the greatest westto-east difference $\left(0.74 \mathrm{mmol} \mathrm{m}^{-3}\right.$ in on-shelf waters) was found with the lowest concentrations $(0.18 \pm$ $0.08 \mathrm{mmol} \mathrm{m}^{-3}$ ) throughout the 3 surveys in western waters.
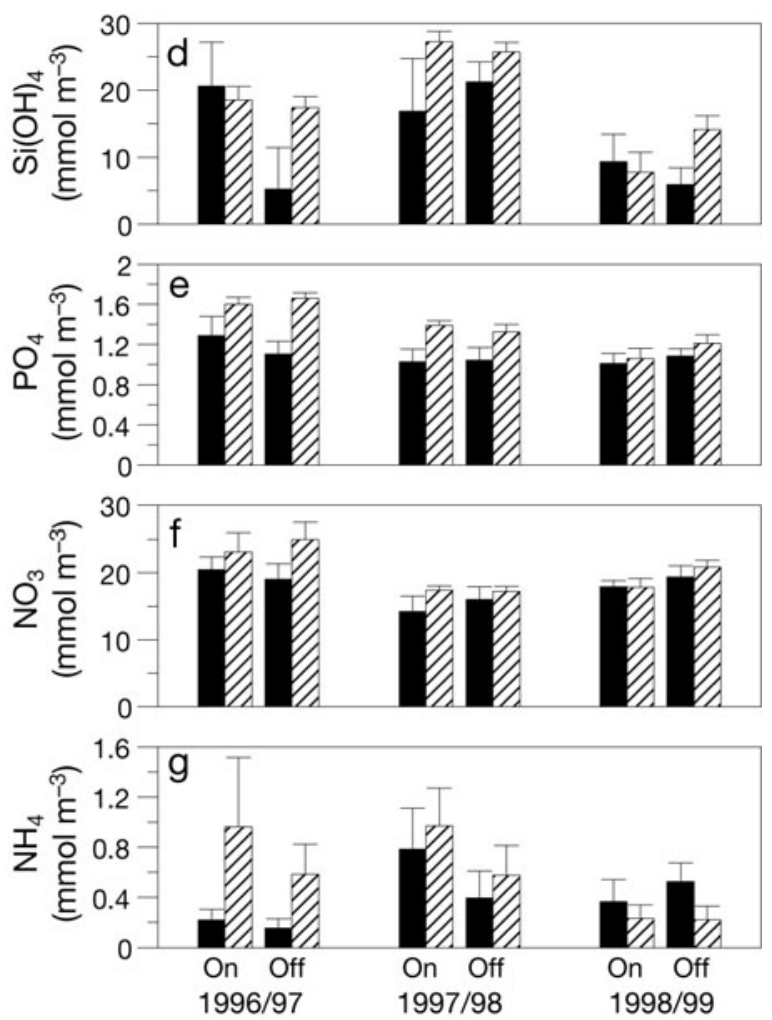

Fig. 2. Mean (+SD) values for the west and east (key in b), on- and off-shelf sub-regions during the 3 sampling years. (a) Chl a, (b) Euphausia superba density, (c) temperature, (d) $\mathrm{Si}(\mathrm{OH})_{4}$, (e) $\mathrm{PO}_{4}$, (f) $\mathrm{NO}_{3}$, (g) $\mathrm{NH}_{4}$. (b) Particularly large SD of krill density are noted on the plot as opposed to being graphically represented 


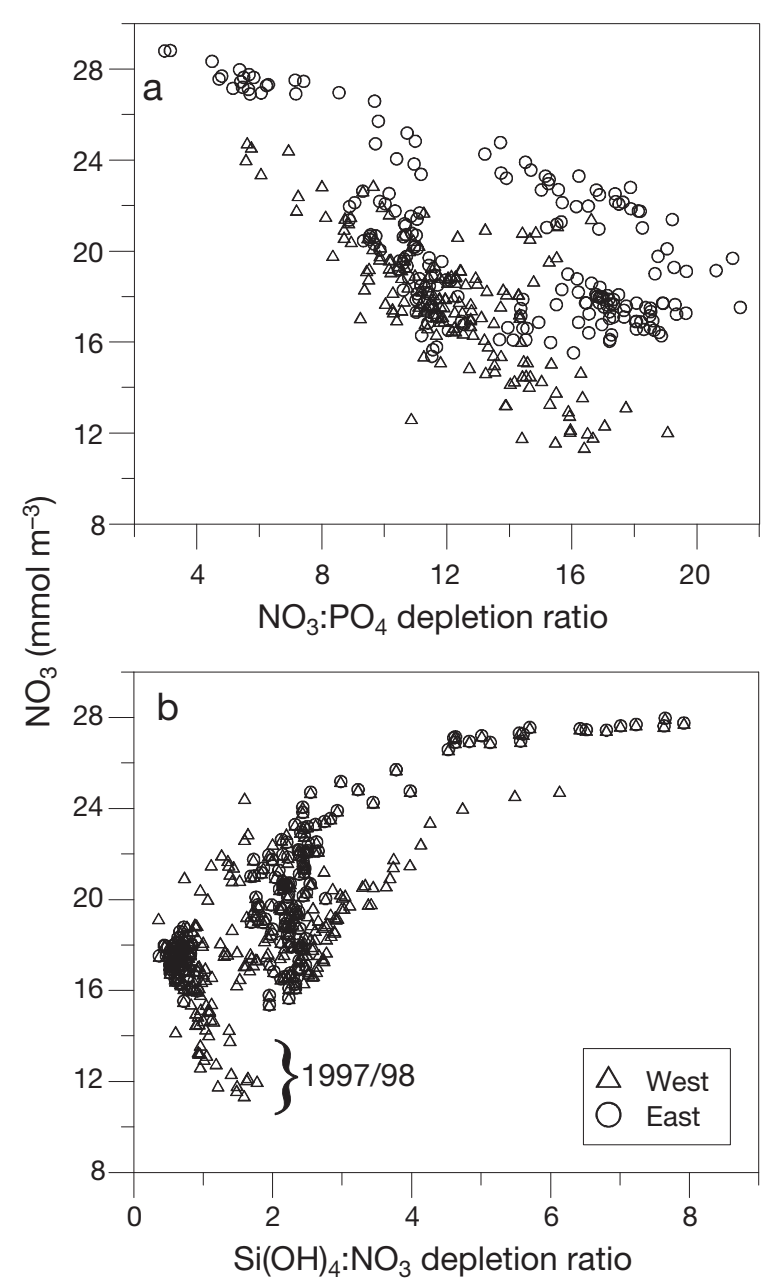

Fig. 3. Ambient $\mathrm{NO}_{3}$ concentration in the west and the east survey areas compared to (a) $\mathrm{NO}_{3}: \mathrm{PO}_{4}$ depletion ratios, (b) $\mathrm{Si}(\mathrm{OH})_{4}: \mathrm{NO}_{3}$ depletion ratios

\section{Relationships between chl $\boldsymbol{a}$ and krill, temperature and nutrients}

The relationship between chl $a$ and krill is complex, and a year-by-year comparison indicated a highly variable and non-linear relationship (Fig. 4a). In summers with abundant krill, 1996/97 and 1997/98, the GAMs showed domed relationships with the respective $\log _{10}$ chl a peaks of 0.62 and $0.35 \mathrm{mg} \mathrm{m}^{-3}$ at $\log _{10} \mathrm{krill}$ of 0.81 and $1.0 \mathrm{~g} \mathrm{~m}^{-2}$. There was a relatively flatter response for $1998 / 99$ with a $0.52 \mathrm{mg} \mathrm{m}^{-3} \log _{10} \mathrm{chl}$ a peak at a $\log _{10}$ krill density of $1.47 \mathrm{~g} \mathrm{~m}^{-2}$. To summarise, in real terms, the GAMs indicated chl a peaks between 2.2 and $4.2 \mathrm{mg} \mathrm{m}^{-3}$ at krill densities between 6.5 and $29.5 \mathrm{~g} \mathrm{~m}^{-2}$.

If we consider data from within our sub-regions, then some distinct chl a/krill trends emerge. The west offshelf sub-region is atypical with chl a concentrations positively related to krill abundance (Fig. 5a). Overall, and for the 1998/1999 summer, this relationship is highly significant $(\mathrm{p}<0.001)$. In all other sub-regions, chl a concentrations are negatively related to krill abundance. Overall, the relationship is highly significant $(p<0.001)$ in both east off- and on-shelf waters where krill are most abundant, but it is also negative in west on-shelf waters $(\mathrm{p}<0.01)$.

During the first 2 surveys, chl a related positively to temperature. A smaller range of values appeared to produce a slightly negative relationship in 1998/99 (Fig. 4b). Highest concentrations of chl a were generally confined to waters $>2{ }^{\circ} \mathrm{C}$.

There was a consistently negative relationship between chl $a$ and $\mathrm{Si}(\mathrm{OH})_{4}, \mathrm{PO}_{4}$ and $\mathrm{NO}_{3}$ (Fig. 4c, d,e), but note the smaller range of data measured during 1998/99. High chl a values during 1996/97 coincided with very low $\mathrm{Si}(\mathrm{OH})_{4}$ concentrations. By contrast, a large part of the 1997/98 survey was conducted in low chl a waters where $\mathrm{Si}(\mathrm{OH})_{4}$ remained close to prebloom, winter concentrations (Whitehouse et al. 1996, 2000). However, this apparent under-utilisation of $\mathrm{Si}(\mathrm{OH})_{4}$ in $1997 / 98$ was in stark contrast with $\mathrm{PO}_{4}$ and $\mathrm{NO}_{3}$ use, when some of the lowest concentrations for these nutrients were measured. A negative relationship between chl $a$ and $\mathrm{NH}_{4}$ appeared to be consistent for the 2 earlier surveys, but a small $\mathrm{NH}_{4}$ range in 1998/99 resulted in virtually no relationship with chl a (Fig. 4f).

\section{Multivariate examination of chl a variability}

Given the hydrological dynamics around South Georgia with rapid current flow in off-shelf waters (primarily east to west; Fig. 1c) and a varying degree of water retention over its shelf (Meredith et al. 2005), we assessed chl a variability separately for the on- and offshelf regions. We modelled $\log _{10}$ chl a concentration variability with year, longitude, $\log _{10}$ krill density, temperature and nutrient concentrations as explanatory factors (Table 2). Longitude was a significant ( $p<$ 0.001) explanatory factor in both on-shelf and off-shelf waters. Also, for on-shelf waters, krill, temperature, $\mathrm{Si}(\mathrm{OH})_{4}$ and $\mathrm{NH}_{4}$ were highly significant predictors, and the model explained $\sim 83 \%$ of chl a variability. For off-shelf waters, with the exception of krill and $\mathrm{Si}(\mathrm{OH})_{4}$, all predictors were highly significant $(\mathrm{p}<$ 0.001 ), and the model explained $\sim 80 \%$ of chl a variability. Significantly higher concentrations of chl a occurred in the west, as has been documented previously (e.g. Atkinson et al. 2001, Korb et al. 2004), so to further explore the relative roles of the predictor variables, it was necessary to consider the on- and off-shelf sub-regions separately in the west and east surveys. 
For the west on-shelf sub-region, $\mathrm{NH}_{4}$ was the most significant predictor variable for chl a concentration, while $\mathrm{Si}(\mathrm{OH})_{4}(F=3.7, \mathrm{p}=0.06)$ and krill $(F=3.4, \mathrm{p}=$ 0.07 ) were near-significant (Table 2). These variables were all negatively related and together with the minor factors explained $\sim 57 \%$ of chl a variability. For the east on-shelf sub-region, longitude remained a significant predictor followed by $\mathrm{Si}(\mathrm{OH})_{4}$ and to a lesser degree $\mathrm{NH}_{4}$ and krill. Both nutrients and krill were negatively related and together with the minor factors
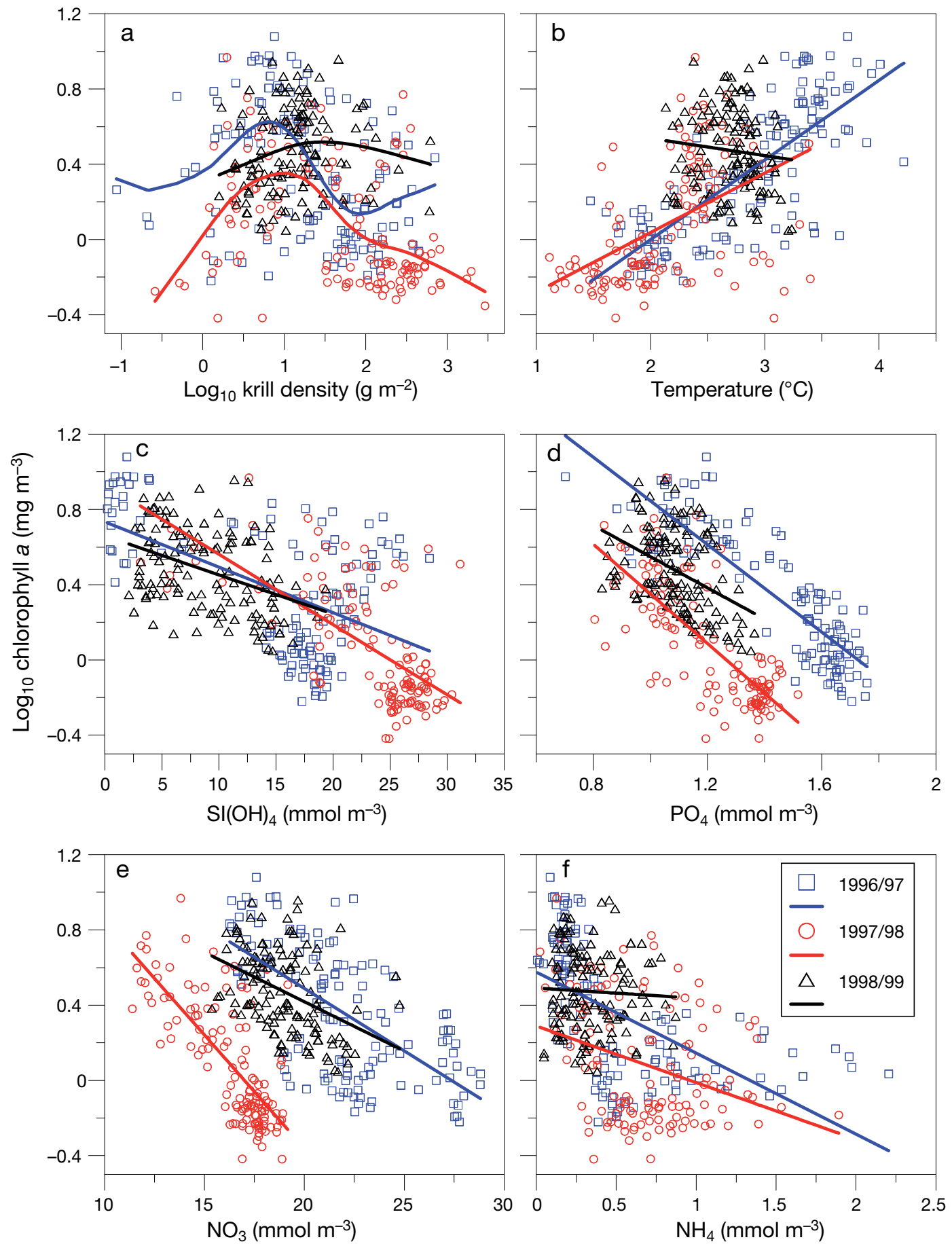

Fig. 4. Relationship during the 3 sampling years (identified in $\mathrm{f}$ ) of $\log _{10}$ chl a with (a) $\log _{10}$ Euphausia superba density, (b) temperature, (c) $\mathrm{Si}(\mathrm{OH})_{4}$, (d) $\mathrm{PO}_{4}$, (e) $\mathrm{NO}_{3}$, (f) $\mathrm{NH}_{4}$. For the $\log _{10}$ krill density comparisons, generalised additive models were used and the degrees of freedom were 5 for years 1996/97 and 1997/98 and 3 for 1998/99. The other relationships are simple linear regression lines to indicate trends 

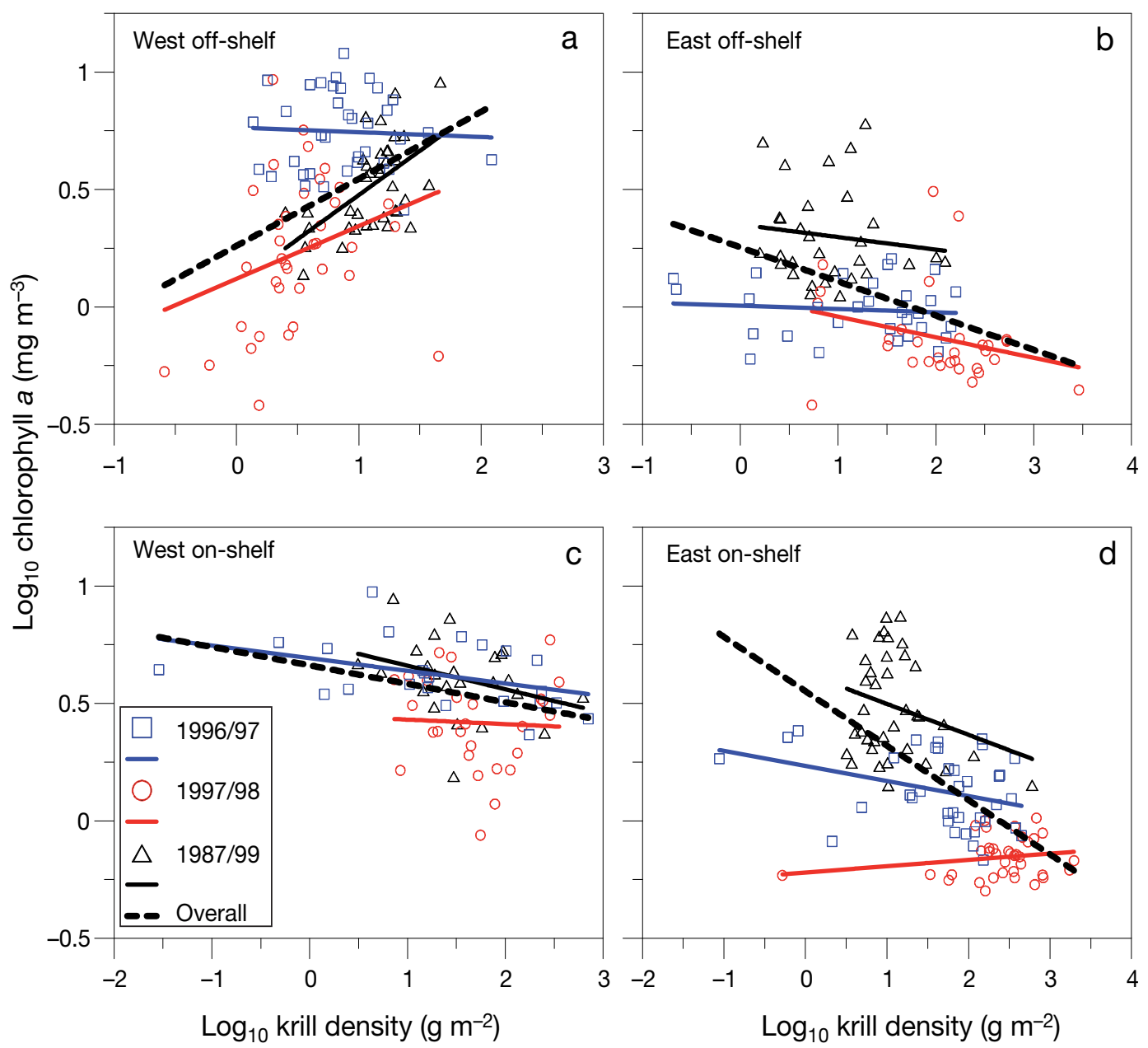

Fig. 5. Relationship between $\log _{10} \mathrm{chl} a$ and $\log _{10}$ Euphausia superba density during the 3 sampling years and overall (identified in c) in the sub-regions (a) west off-shelf, (b) east off-shelf, (c) west on-shelf, (d) east on-shelf. Simple linear regression lines are used to indicate trends. Note the different $x$-axis scales used for each panel

Table 2. Summary of general linear model relating $\log _{10}$ chlorophyll to longitude, $\log _{10}$ Euphausia superba, temperature, $\mathrm{Si}(\mathrm{OH})_{4}, \mathrm{PO}_{4}, \mathrm{NO}_{3}, \mathrm{NH}_{4}$ and year (as a categorical variable). Regional coefficients (standard error) are detailed and significant slopes are indicated thus: ${ }^{* * *} \mathrm{p}<0.001,{ }^{* *} \mathrm{p}<0.01,{ }^{*} \mathrm{p}<0.05$. The year effects are deviations around zero

\begin{tabular}{|c|c|c|c|c|c|c|}
\hline & $\overline{\text { West and East }} \mathrm{O}$ & $\begin{array}{l}\text { n-shelf }(<1000 \mathrm{~m} \\
\text { West only }\end{array}$ & East only & West and East & $\begin{array}{c}\text { Off-shelf }(>1000 \mathrm{~m}) \\
\text { West only }\end{array}$ & East only \\
\hline $\mathrm{R}^{2}$ & $83 \%$ & $57 \%$ & $87 \%$ & $80 \%$ & $78 \%$ & $77 \%$ \\
\hline Longitude & $-0.10(0.01)^{* * *}$ & $-0.03(0.05)$ & $-0.31(0.04)^{* * *}$ & $-0.08(0.01)^{* * *}$ & $-0.06(0.05)$ & $-0.30(0.07)^{* * *}$ \\
\hline $\log _{10}$ krill & $-0.07(0.02)^{* * *}$ & $-0.05(0.03)$ & $-0.04(0.02)^{*}$ & $-0.01(0.02)$ & $0.08(0.05)$ & $-0.06(0.02)^{* *}$ \\
\hline Temperature & $0.13(0.04)^{* * *}$ & $0.08(0.08)$ & $-0.05(0.05)$ & $-0.22(0.04)^{* * *}$ & $-0.36(0.08)^{* * *}$ & $-0.09(0.06)$ \\
\hline $\mathrm{Si}(\mathrm{OH})_{4}$ & $-0.01(0.003)^{* * *}$ & $-0.01(0.003)$ & $-0.02(0.01)^{* * *}$ & $-0.01(0.004)^{*}$ & $-0.01(0.01)^{*}$ & $-0.02(0.01)$ \\
\hline $\mathrm{PO}_{4}$ & $-0.05(0.13)$ & $0.03(0.17)$ & $-0.15(0.19)$ & $-0.51(0.15)^{* * *}$ & $-0.15(0.20)$ & $-1.23(0.26)^{* * *}$ \\
\hline $\mathrm{NO}_{3}$ & $-0.004(0.01)$ & $-0.01(0.01)$ & $0.0003(0.01)$ & $-0.03(0.01)^{* * *}$ & $-0.04(0.01)^{* * *}$ & $-0.02(0.01)$ \\
\hline $\mathrm{NH}_{4}$ & $-0.17(0.03)^{* * *}$ & $-0.29(0.09)^{* *}$ & $-0.09(0.04)^{*}$ & $-0.40(0.07)^{* * *}$ & $-0.50(0.10)^{* * *}$ & $-0.21(0.09)^{*}$ \\
\hline 1996/97 & $0.025(0.04)$ & $0.04(0.06)$ & $0.07(0.06)$ & $0.29(0.04)^{* * *}$ & $0.37(0.07)^{* * *}$ & $0.33(0.09)^{* * *}$ \\
\hline $1997 / 98$ & $-0.05(0.04)$ & $-0.04(0.06)$ & $-0.05(0.09)$ & $-0.34(0.06)^{* * *}$ & $-0.38(0.09)^{* * *}$ & $-0.21(0.10)^{*}$ \\
\hline $1998 / 99$ & $0.025(0.03)$ & $0.001(0.04)$ & $-0.02(0.08)$ & $0.06(0.03)^{*}$ & $0.01(0.05)$ & $-0.12(0.07)^{*}$ \\
\hline
\end{tabular}


explained $\sim 87 \%$ of chl a variability. For the west offshelf sub-region, temperature was the most significant explanatory factor followed by $\mathrm{NH}_{4}$, then $\mathrm{NO}_{3}$ and to a lesser degree $\mathrm{Si}(\mathrm{OH})_{4}$. The nutrients were negatively related to chl $a$, as was temperature, and with the minor factors they explained $\sim 78 \%$ of $\mathrm{chl}$ a variability. For the east off-shelf sub-region, $\mathrm{PO}_{4}$ was the most significant explanatory factor along with longitude followed by krill and $\mathrm{NH}_{4}$. $\mathrm{PO}_{4}$ and krill were negatively related to chl $a$, and together with the minor factors explained $\sim 77 \%$ of its variability. When considering these 4 sub-regions, $\mathrm{NH}_{4}$ was the most important predictor and was significant in all of them. Longitude, $\mathrm{Si}(\mathrm{OH})_{4}$ and krill were the next most important predictors, followed by $\mathrm{NO}_{3}, \mathrm{PO}_{4}$ and temperature.

The year coefficients give an indication of temporal variability in the system (Table 2). On-shelf measurements were consistent throughout, whereas most of those off-shelf contained significant year-to-year variability.

\section{DISCUSSION}

These 3 surveys illustrate the variability that exists between macronutrients, phytoplankton abundance and krill density within a relatively small area, roughly $330 \mathrm{~km}$ wide. Most of this variability is due to the influence of the extensive shelf of South Georgia and its location relative to the major fronts of the ACC. The Scotia Arc steers the generally eastward flowing ACC northwards past South Georgia so that the usual northsouth temperature gradients associated with the ACC are rotated counter-clockwise as they pass the island. If our chl $a$ and krill data are considered in relation to this local west-east temperature gradient, it is apparent that the warmer western waters hold a greater standing stock of phytoplankton while the colder waters to the east hold greater densities of krill (Fig. 6). The present dataset allows us to make observations over multiple trophic levels. Below we examine the evidence for bottom-up and top-down controls on phytoplankton stocks at the mesoscale.

\section{Bottom-up controls on phytoplankton}

Over large scales, bottom-up controls on phytoplankton appear to be dominant. In addition to the major west-east gradient across the ACC, the presence of the South Georgia shelf had a major influence. The retention of water over the island's shelf has major physical and chemical implications for the region's primary production (e.g. Meredith et al. 2005, Whitehouse et al. 2008). Our model indicated year-to-year
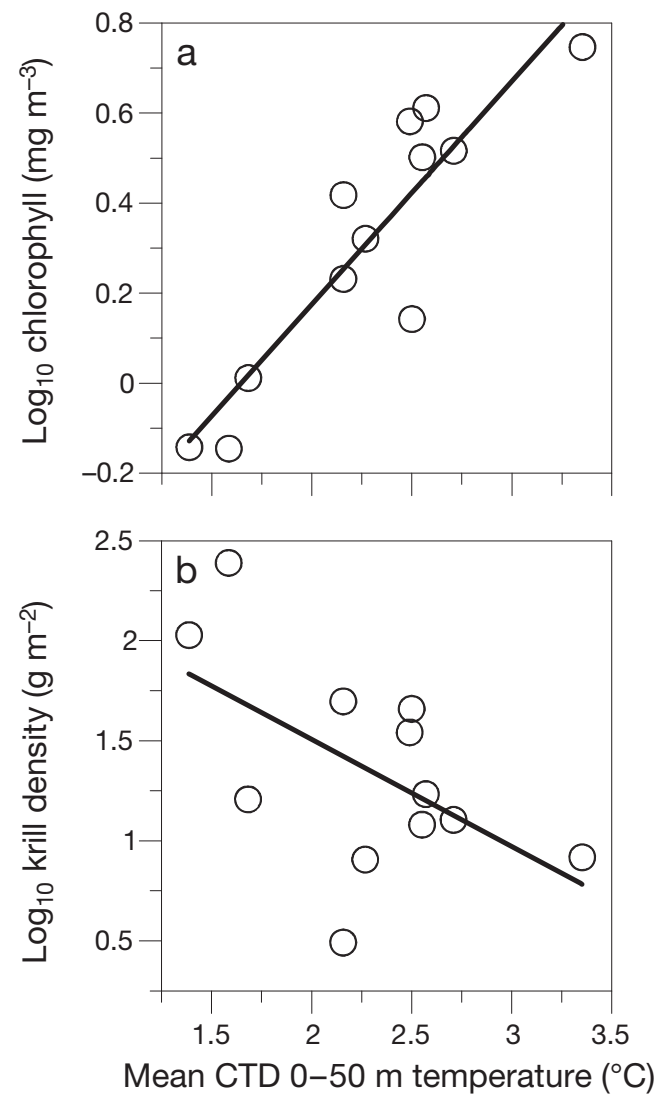

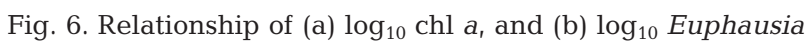
superba density with mean CTD 0 to $50 \mathrm{~m}$ temperature. Data points represent mean west and east, on- and off-shelf values for the sub-regions during the 3 sampling years

consistency over the island shelf, whereas there was significant inter-annual variability in off-shelf waters, particularly in 1996/97 and 1997/98. During these 2 earlier surveys, on- and off-shelf waters lay either side of a distinct shelf-break front, whereas during 1998/99 there was little difference between on- and off-shelf water mass densities (Meredith et al. 2005). This may account for the consistency found throughout the subregions during 1998/99 and infers exchange between on- and off-shelf waters during that season. Conversely, retention over the island shelf during the earlier surveys might buffer year-to-year variability, while rapidly flowing off-shelf waters are more susceptible to remote change (Meredith et al. 2005).

In both on- and off-shelf regions, chl a concentrations in the west were greater than those in the east (Fig. 2), and this was paralleled by 5 - to 9 -fold greater primary production rates (Table 3 ). This could reflect higher water temperatures in the west, which might promote $\mathrm{NO}_{3}$ uptake (Reay et al. 2001, Shreeve et al. 2002). Indeed, our analyses of all on-shelf and all offshelf regions included temperature as a significant 
Table 3. Sub-region mean (plus range where available) primary production rates $\left(\mathrm{g} \mathrm{C} \mathrm{m}^{-2} \mathrm{~d}^{-1}\right)$ integrated over the euphotic zone (apart from the season 2002/03 that is over $100 \mathrm{~m}$ ). -: no data

\begin{tabular}{|c|c|c|c|c|c|}
\hline \multirow{2}{*}{ Season } & \multicolumn{2}{|c|}{ On-shelf $(<1000$ m) } & \multicolumn{2}{|c|}{ Off-shelf (>1000 m) } & \multirow[t]{2}{*}{ Source } \\
\hline & West & East & West & East & \\
\hline 1993/94 & - & 0.07 & 1.66 & - & Pakhomov et al. (1997b) \\
\hline 1995/96 & $1.48(0.84-2.48)$ & 0.52 & 1.63 & $0.27(0.20-0.34)$ & Gilpin et al. (2002) \\
\hline 2001/02 & $0.78(0.58-1.15)$ & $0.14(0.12-0.14)$ & $1.18(0.15-2.50)$ & $0.12(0.06-0.16)$ & Korb \& Whitehouse (2004) \\
\hline $2002 / 03$ & $2.10(0.84-3.34)$ & - & $1.97(1.25-2.55)$ & - & Korb et al. (2005) \\
\hline $2004 / 05$ & $0.50(0.36-0.64)$ & - & $0.81(0.57-1.38)$ & - & Whitehouse et al. (2008) \\
\hline Mean & 1.22 & 0.24 & 1.81 & 0.20 & - \\
\hline
\end{tabular}

predictor. However, at a smaller scale, temperature remained a significant predictor in one sub-region only, the west off-shelf, where it varied negatively with chl a. This suggests that temperature per se is not the main predictor of chl a variability, and instead, elevated phytoplankton growth is facilitated by other factors and happens to occur in warm waters to the west.

Our data show a close relationship between phytoplankton standing stock and nutrient use with lowest ambient nutrient concentrations evident in the west. High phytoplankton standing stock and growth rates in waters northwest and downstream of South Georgia have been attributed to relief from Fe stress (e.g. Korb \& Whitehouse 2004), brought about by sedimentary flux from the island's extensive shelf and/or upwelling of deep nutrient-rich waters. Relief from Fe stress would allow greater utilisation of $\mathrm{NO}_{3}$, and indeed, our GLM indicates that $\mathrm{NO}_{3}$ is a significant predictor of chl $a$ in west off-shelf waters, downstream of the island mass (Table 2). However, $\mathrm{NH}_{4}$ was also a significant factor in this sub-region, indicating that both $\mathrm{N}$ sources were important downstream of South Georgia. In all other sub-regions, recycled $\mathrm{NH}_{4}$ was the most important $\mathrm{N}$ source.

Temperature's negative relationship with chl $a$ in west off-shelf waters might be related to the upwelling of cool, nutrient-rich water (Meredith et al. 2005). The magnitude and longevity of blooms to the west are dependent on a persistent supply of macro- and micronutrients from upstream or via upwelling or rapid recycling. Mean chl a concentration was $3.9 \mathrm{mg} \mathrm{m}^{-3}$ ( 0.4 to $12.0 \mathrm{mg} \mathrm{m}^{-3}$ ), and satellite images indicated that blooms of this magnitude persisted between December and March in all 3 yr of this study (see Korb et al. 2004 and ocean color and temperature scanner [OCTS] data on the NASA Ocean Color website: http://oceancolor.gsfc.nasa.gov/). Typical primary production rates of 0.8 to $1.8 \mathrm{~g} \mathrm{C} \mathrm{m}^{-2} \mathrm{~d}^{-1}$ (Table 3) would total 96 to $216 \mathrm{~g}$ $\mathrm{C} \mathrm{m}^{-2} 120 \mathrm{~d}^{-1}$ (4 mo). Assuming Redfield uptake ratios,

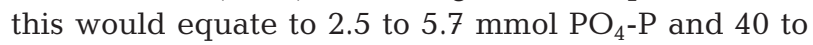
$91 \mathrm{mmol} \mathrm{NO}-\mathrm{N}$ over a typical euphotic depth of $\sim 30 \mathrm{~m}$ (Korb \& Whitehouse 2004). With typical winter concen- trations of 2.1 and $30 \mathrm{mmol} \mathrm{m}{ }^{-3}$ for $\mathrm{PO}_{4}$ and $\mathrm{NO}_{3}$, respectively (BAS unpubl. data), re-supply of nutrients through, for instance, upwelling or recycling as indicated by $\mathrm{NH}_{4}$ use (Table 2), must occur.

Another aspect to the $\mathrm{N}$ preference of phytoplankton is evidenced by both $\mathrm{NO}_{3}$ and $\mathrm{NH}_{4}$ being significant predictors in west off-shelf waters. High $\mathrm{NH}_{4}$ concentrations and utilisation would usually inhibit nitrate uptake (Armstrong 1999). Given that simultaneous $\mathrm{NO}_{3}$ and $\mathrm{NH}_{4}$ use is implausible, perhaps patchiness in Fe availability (facilitating $\mathrm{NO}_{3}$ use) or grazer distribution (resulting in available $\mathrm{NH}_{4}$ ) enables the alternating use of both $\mathrm{N}$ sources. This may be an important contributory factor for higher primary production rates in the west as well as the exceptional longevity of the region's bloom.

$\mathrm{Si}(\mathrm{OH})_{4}$ was a highly significant predictor of chl $a$ in east, on-shelf regions, with lower significant values evident in all other regions, which is due to the usual dominance of diatoms in the system. However, 1997/98 was atypical in 2 respects. For this year, Meredith et al. (2005) described the passage of a cold, large-scale ocean anomaly. Unusually, water density was higher over the island's shelf relative to off-shelf waters and the net baroclinic flow was cyclonic or eastwards along the northern shelf-break. Cyclonic flow around South Georgia is the opposite direction to the general circulation offshore and would lead to stronger lateral shear and greater barotropic frontal instability (Meredith et al. 2005). This increased potential for the transfer of water between the shelf and the open ocean may have resulted in a greater availability of micronutrients from deep water and/or shelf sediment. In turn, this facilitated more efficient $\mathrm{NO}_{3}$ utilisation than is usually the case, as indicated by near-Redfield depletion ratios of $\sim 16: 1 \quad \mathrm{NO}_{3}: \mathrm{PO}_{4}$ and $\sim 1: 1 \mathrm{Si}(\mathrm{OH})_{4}: \mathrm{NO}_{3}$ (Fig. 3). Secondly, the greatest apparent $\mathrm{NO}_{3}$ and $\mathrm{PO}_{4}$ depletions occurred during this season while $\mathrm{Si}(\mathrm{OH})_{4}$ concentrations remained relatively high. Conditions appear to have favoured non-diatom phytoplankton growth that is atypical for South Georgia (see Korb \& Whitehouse 2004). 


\section{Top-down control on phytoplankton}

Our GLM identified krill as a significant predictor of chl $a$ in the east (Table 2), and our examination of subregions (Fig. 5) confirmed that they were negatively related in eastern waters. A negative relationship might be expected if grazing pressure has an important control on phytoplankton. Our model indicated that krill was not a significant predictor of chl $a$ in western waters but did indicate a positive relationship in the west off-shelf sub-region, which was supported by our examination of sub-regions.

If we consider krill ingestion estimates in east offshelf waters for 1997/98 when krill density was high (mean $260 \mathrm{~g} \mathrm{~m}^{-2}$ ) and phytoplankton abundance was

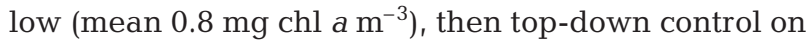
phytoplankton appears inevitable. The $260 \mathrm{~g}$ wet mass

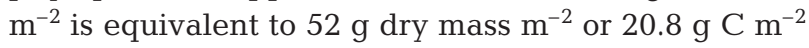
(using relationships in Morris et al. 1988 and Schnack 1985). With a $\mathrm{C}$ ration of $\sim 5 \% \mathrm{~d}^{-1}$ measured at South Georgia (Pakhomov et al. 1997a, b), krill would con-

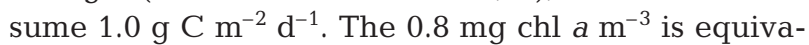
lent to $40 \mathrm{mg} \mathrm{C} \mathrm{m}^{-3}$ (using a $\mathrm{C}$ :chl a ratio of 50), which, over a typical $75 \mathrm{~m}$ surface mixed layer (Korb \& Whitehouse 2004), equals $3 \mathrm{~g} \mathrm{C} \mathrm{m}^{-2}$. So, notwithstanding other grazers, the ingestion by krill alone would remove $33 \%$ of phytoplankton per day. Similarly, if we compare krill ingestion to primary production (mean of $0.2 \mathrm{~g} \mathrm{C} \mathrm{m}^{-2} \mathrm{~d}^{-1}$; Table 3), then krill would appear to consume on average 5 times the daily primary production.

The krill daily carbon ration used for this calculation $(5 \%)$ is not excessive given that their maximum daily ration is probably about 13 to $27 \%$ (Clarke et al. 1988, Pakhomov et al. 1997b). An independent grazing rate can be derived from gross growth rates of $1 \%$ of krill mass $d^{-1}$ measured for northern South Georgia (Atkinson et al. 2006). Based on a gross growth efficiency of $30 \%$ (Straile 1997), the daily ration would be $3.3 \%$. Whether based on a ration of 3.3 or $5 \%$, high concentrations of krill within the east off-shelf region are likely to have a substantial grazing effect on phytoplankton.

Over the South Georgia shelf, krill are also likely to have a substantial grazing effect, especially in the east on-shelf sub-region where their densities can be high. Here, however, our GLM showed a weaker negative relationship between krill density and chl a compared to east off-shelf waters. How dense krill swarms interact with their food sources in shallow shelf regions is poorly known and beyond the scope of the present dataset. However, a possible explanation for our weaker on-shelf GLM relationships is that the krill here had switched to alternative food sources such as copepods or heterotrophic flagellates (Atkinson \&
Snÿder 1997, Pakhomov et al. 1997a, Schmidt et al. 2006). Indeed, in any area with several hundred $g$ of krill under $1 \mathrm{~m}^{2}$, our calculated removal of about onethird of phytoplankton stocks per day is clearly unsustainable (Atkinson et al. 2001). Additional mitigating factors in these regions may include decreased daily rations, feeding on competing grazers or on detritus, and high excretion of $\mathrm{NH}_{4}$ to promote plant growth.

South Georgia contains some of the highest krill densities anywhere in the Southern Ocean (Atkinson et al. 2008), but densities can also be very low here. If we consider krill ingestion estimates in west off-shelf waters for 1997/98 when krill density was low (mean $5.1 \mathrm{~g} \mathrm{~m}^{-2}$ ) and phytoplankton abundance was high

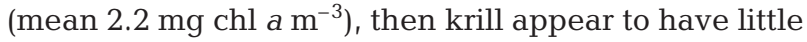
grazing effect. The $5.1 \mathrm{~g}$ wet mass $\mathrm{m}^{-2}$ equates to $\sim 0.41 \mathrm{~g} \mathrm{C} \mathrm{m}^{-2}$ using the same relationships as above. With a $\mathrm{C}$ ration of $5 \% \mathrm{~d}^{-1}$, krill would consume $0.02 \mathrm{~g}$

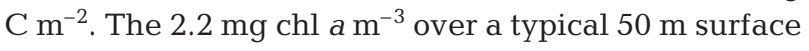
mixed layer (Korb \& Whitehouse 2004) equates to $\sim 5.5 \mathrm{~g} \mathrm{C} \mathrm{m}^{-2}$. Therefore, krill ingestion would remove $0.4 \%$ of phytoplankton per day. As a proportion of primary production $\left(\right.$ mean $=1.81 \mathrm{~g} \mathrm{C} \mathrm{m}^{-2} \mathrm{~d}^{-1}$; Table 3 ), krill would remove $\sim 1 \% \mathrm{~d}^{-1}$.

\section{Overall perspective}

A previous station-based analysis of nutrients, phytoplankton and grazers (Shreeve et al. 2002) concluded that the colder waters to the east of South Georgia contained more krill because of their more recent advection from farther south, while the warmer waters to the west were more favourable for phytoplankton growth. Our larger dataset does not contradict this view but does implicate nutrients as the key factors facilitating phytoplankton growth in the west and suggests a greater interaction between krill and phytoplankton.

Throughout the region, $\mathrm{NH}_{4}$ appears to be a key $\mathrm{N}$ source facilitating primary production. However, the addition of $\mathrm{NO}_{3}$ as a significant predictor of chl $a$ in west off-shelf waters may be critical in facilitating the major blooms that occur in this region (Korb et al. 2004), and Fe availability rather than temperature may be the primary control here. The data also suggest a link between $\mathrm{NH}_{4}$ availability and krill distribution; note the concurrent reduction of krill abundance and $\mathrm{NH}_{4}$ concentrations in 1998/99 (Figs. 2 \& 4). Experiments suggested that krill excretion in the eastern area could supply 16 to $50 \%$ of the $\mathrm{NH}_{4}$ demand here (Atkinson \& Whitehouse 2000), while other metazoans (copepods and small euphausiids) would contribute a similar amount (Atkinson \& Whitehouse 2001). However, given the likely short residence times and reac- 


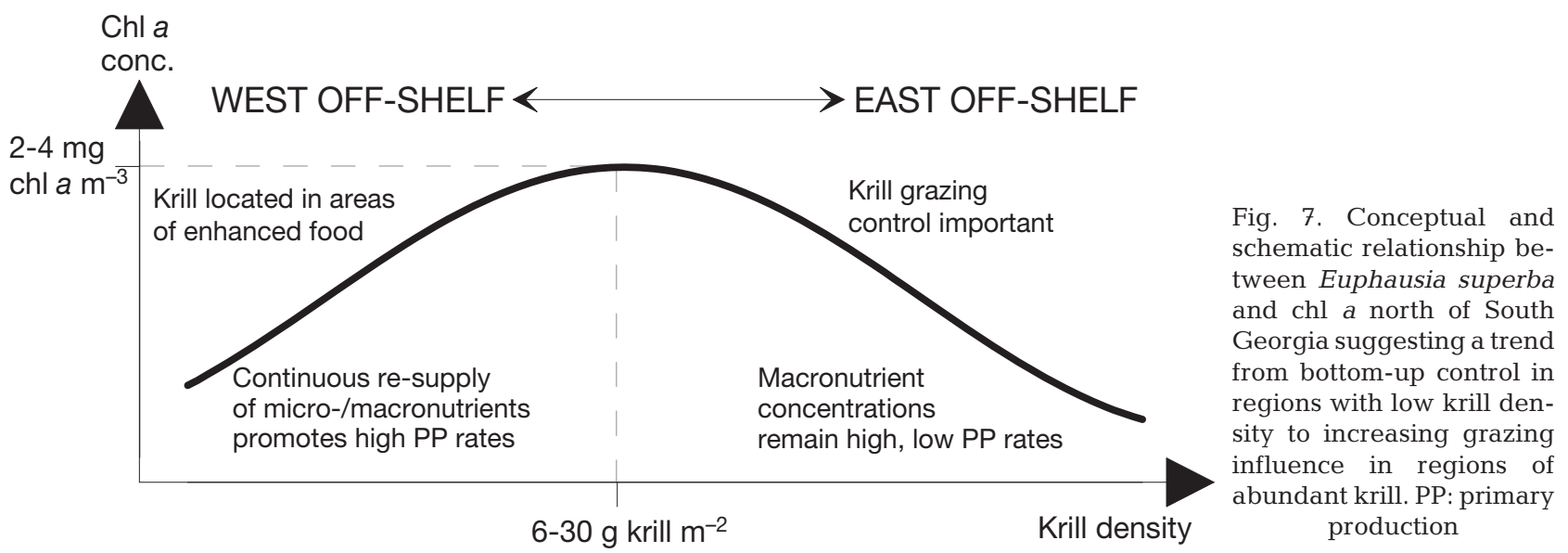

tivity of $\mathrm{NH}_{4}$, these dynamics and feedbacks would be difficult to investigate in a field study such as ours.

While the dynamics of controls on phytoplankton in areas of exceptionally high krill biomass remain speculative, our data allow some generalisations for South Georgia (Fig. 7). The data show a contrasting relationship between krill and phytoplankton in the west offshelf region (positive) compared to the rest of the surveyed area (negative). Thus the positive and negative relationships for the various sub-regions (Fig. 5) seem to represent the opposing slopes on either side of this dome. The re-supply of micro- and macronutrients in the west is sufficient to promote high rates of primary production in an area of low krill density, and the krill are located where their food is. This convergence may be due to physical forcing, or perhaps krill are able to maintain their position where grazing opportunities are best. In the east and over parts of the shelf, macronutrient concentrations remain high, primary production rates are low and grazing pressure is implicated.

The actual mechanisms of the krill-food interaction would probably occur at a smaller spatial scale, for example, at the scales of mobile krill swarms that contain actively feeding individuals (Antezana \& Ray 1984, Schmidt et al. 2006). However, logic would suggest that the mechanism of the various bottom-up and top-down controls varies greatly in time and space. This would explain the range of positive and negative krill-food relationships reported in the literature at different scales (e.g. Weber et al. 1986, Atkinson et al. 2008). Overall, the relative importance of top-down and bottom-up controls varies both with scale of observation and with local predator densities.

In high latitude environments as elsewhere in the world ocean, protozoans tend to be the main grazers of phytoplankton (Calbet \& Landry 2004). This also holds generally in the Southern Ocean, where the grazing effect of metazoans is often found to be small (e.g.
Urban-Rich 2001, Dubischar \& Bathmann 1997). South Georgia can provide an exception to this rule, where metazooplankton as well as krill biomass is high, and their grazing effect can be significant (Pakhomov et al. 1997a,b, Atkinson et al. 2001). However, at the mesoscale it is likely that the distribution of protozoans and copepods is much more even than that of krill, so their grazing can be envisaged as a 'background' on which the krill are superimposed. Krill density varies greatly at the mesoscale and can be measured acoustically, allowing us glimpses of the simultaneous topdown and bottom-up controls on phytoplankton.

Acknowledgements. We thank the officers, crew and scientific parties involved with data collection during cruises JR17, JR28 and JR38. We particularly thank J. Watkins for the collection of krill density data, J. Priddle for chlorophyll analysis, A. Rees for assistance with nutrient analysis and A. Wood for help with data analysis. In addition, we acknowledge 4 anonymous referees whose constructive comments enabled us to improve our analysis.

\section{LITERATURE CITED}

Antezana T, Ray K (1984) Active feeding of Euphausia superba in a swarm north of Elephant Island. J Crustac Biol 4:142-155

Armstrong RA (1999) An optimisation-based model of ironlight-ammonium colimitation of nitrate uptake and phytoplankton growth. Limnol Oceanogr 44:1436-1446

Atkinson A, Snÿder R (1997) Krill-copepod interactions at South Georgia, Antarctica, I. Omnivory by Euphausia superba. Mar Ecol Prog Ser 160:63-76

Atkinson A, Whitehouse MJ (2000) Ammonium excretion by Antarctic krill, Euphausia superba at South Georgia. Limnol Oceanogr 45:55-63

Atkinson A, Whitehouse MJ (2001) Ammonium regeneration by Antarctic mesozooplankton: an allometric approach. Mar Biol 139:301-311

Atkinson A, Whitehouse MJ, Priddle J, Cripps GC, Ward P, Brandon MA (2001) South Georgia, Antarctica: a productive, cold water, pelagic ecosystem. Mar Ecol Prog Ser 
216:279-308

Atkinson A, Shreeve RS, Hirst AG, Rothery P and others (2006) Natural growth rates of Antarctic krill (Euphusia superba): II. Predictive models based on food, temperature, body length, sex, and maturity stage. Limnol Oceanogr 51:973-987

Atkinson A, Siegel V, Pakhomov EA, Rothery P and others (2008) Oceanic circumpolar habitats of Antarctic krill. Mar Ecol Prog Ser 362:1-23

Boyd PW, Jickells T, Law CS, Blain S and others (2007) Mesoscale iron enrichment experiments 1993-2005: synthesis and future directions. Science 315:612-617

Brandon MA, Murphy EJ, Trathan PN, Bone DG (2000) Physical oceanographic conditions to the northwest of the subAntarctic island of South Georgia. J Geophys Res 105(C10):23983-23996

Brierley AS, Watkins JL, Murray AWA (1997) Interannual variability in krill abundance at South Georgia. Mar Ecol Prog Ser 150:87-98

Brierley AS, Watkins JL, Goss C, Wilkinson MT, Everson I (1999) Acoustic estimates of krill density at South Georgia, 1981 to 1998. CCAMLR Science 6:47-57

Calbet A, Landry MR (2004) Phytoplankton growth, microzooplankton grazing, and carbon cycling in marine systems. Limnol Oceanogr 49:51-57

CCAMLR (2009) Report of the fourth meeting of the subgroup on acoustic survey and analysis methods. SC-CAMLRXXVIII/8, Hobart

Chisholm SW, Morel FMM (eds) (1991) What controls phytoplankton production in nutrient-rich areas of the open sea? Limnol Oceanogr 36:1507-1970

- Clarke A, Quetin LB, Ross RM (1988) Laboratory and field estimates of the rate of faecal pellet production by Antarctic krill, Euphausia superba. Mar Biol 98:557-563

Conti SG, Demer DA (2006) Improved parameterization of the SDWBA for estimating krill target strength. ICES J Mar Sci 63:928-935

Demer DA, Hewitt RP (1995) Bias in acoustic biomass estimates of Euphausia superba due to diel vertical migration. Deep-Sea Res I 42:455-475

> Dubischar CD, Bathmann UV (1997) Grazing impact of copepods and salps on phytoplankton in the Atlantic sector of the Southern Ocean. Deep-Sea Res II 44:415-433

Ducklow HW, Fraser W, Karl DM, Quetin LB and others (2006) Water column processes in the West Antarctic Peninsula and the Ross Sea: interannual variations and foodweb structure. Deep-Sea Res II 53:834-852

Everson I (1982) Diurnal variations in mean volume backscattering strength of an Antarctic krill (Euphausia superba) patch. J Plankton Res 4:155-162

Foote KG, Knudsen HP, Vestnes G, MacLennan DN, Simmonds EJ (1987) Calibration of acoustic instruments for fish density estimation: a practical guide. ICES Cooperative Res Rep 144

- Gilpin LC, Priddle J, Whitehouse MJ, Savidge G, Atkinson A (2002) Primary production and carbon uptake dynamics in the vicinity of South Georgia-balancing carbon fixation and removal. Mar Ecol Prog Ser 242:51-62

Hardy AC, Gunther ER (1935) The plankton of the South Georgia whaling grounds and adjacent waters, 19261927. Discov Rep 11:1-456

> Harris R (2005) The role of zooplankton predator-prey interactions in structuring plankton communities. J Plankton Res 27:957

Hart TJ (1942) Phytoplankton periodicity in Antarctic waters. Discov Rep 21:261-356

Hewitt RP, Watkins J, Naganobu M, Sushin V and others
(2004) Biomass of Antarctic krill in the Scotia Sea in January/February 2000 and its use in revising an estimate of precautionary yield. Deep-Sea Res II 51:1215-1236

> Holeton CL, Nédélec F, Sanders R, Brown L and others (2005) Physiological state of phytoplankton communities in the southwest Atlantic sector of the Southern Ocean, as measured by fast repetition rate fluorometry. Polar Biol 29:44-52

> Houry S, Dombrowsky E, de Mey P, Minster JF (1987) BruntVäisälä frequency and Rossby radii in the South Atlantic. J Phys Oceanogr 17:1619-1626

> Huntley ME, Niiler PP (1995) Physical control of phytoplankton dynamics in the Southern Ocean. ICES J Mar Sci 52:457-468

Korb RE, Whitehouse M (2004) Contrasting primary production regimes around South Georgia, Southern Ocean: large blooms versus high nutrient, low chlorophyll waters. Deep-Sea Res I 51:721-738

Korb RE, Whitehouse MJ, Ward P (2004) SeaWiFS in the Southern Ocean: spatial and temporal variability in phytoplankton biomass around South Georgia. Deep-Sea Res II 51:99-116

Korb RE, Whitehouse MJ, Thorpe SE, Gordon M (2005) Primary production across the Scotia Sea in relation to the physico-chemical environment. J Mar Syst 57:231-249

Korb RE, Whitehouse MJ, Atkinson A, Thorpe SE (2008) Magnitude and maintenance of the phytoplankton bloom at South Georgia: a naturally iron-replete environment. Mar Ecol Prog Ser 368:75-91

> Lawson GL, Wiebe PH, Ashjian CJ, Stanton TK (2008) Euphausiid distribution along the Western Antarctic Peninsula - Part B: distribution of euphausiid aggregations and biomass, and associations with environmental features. Deep-Sea Res II 55:432-454

Martin AP (2003) Phytoplankton patchiness: the role of lateral stirring and mixing. Prog Oceanogr 57:125-174

- Meredith MP, Watkins JL, Murphy EJ, Cunningham NJ and others (2003a) An anticyclonic circulation above the Northwest Georgia Rise, Southern Ocean. Geophys Res Lett 30:2061, doi:10.1029/2003GL018039

> Meredith MP, Watkins JL, Murphy EJ, Ward P and others (2003b) Southern ACC Front to the northeast of South Georgia: pathways, characteristics, and fluxes. J Geophys Res 108(C5):3162, doi:10.1029/2001JC001227

> Meredith MP, Brandon MA, Murphy EJ, Trathan PN and others (2005) Variability in hydrographic conditions to the east and northwest of South Georgia, 1996-2001. J Mar Syst 53:143-167

Morris DJ, Watkins JL, Ricketts C, Bucholz F, Priddle J (1988) An assessment of the merits of length and weight measurements of Antarctic krill Euphausia superba. Br Antarct Surv Bull 79:27-50

Murphy EJ, Watkins JL, Trathan PN, Reid K and others (2007) Spatial and temporal operation of the Scotia Sea ecosystem: a review of large-scale links in a krill centred food web. Phil Trans R Soc B Biol Sci 362:113-148

> Pakhomov EA, Perissinotto R, Froneman PW, Miller DGM (1997a) Energetics and feeding dynamics of Euphausia superba in the South Georgia region during the summer of 1994. J Plankton Res 19:399-423

> Pakhomov EA, Verheye HM, Atkinson A, Laubscher RK, Taunton-Clark J (1997b) Structure and grazing impact of the mesozooplankton community during late summer 1994 near South Georgia, Antarctica. Polar Biol 18: 180-192

> Pakhomov EA, Froneman PW, Perissinotto R (2002) Salp/krill interactions in the Southern Ocean: spatial segregation 
and implications for the carbon flux. Deep-Sea Res II 49: 1881-1907

Parsons TR, Maita Y, Lalli CM (1984) A manual of chemical and biological methods for seawater analysis. Pergamon Press, Oxford

Reay DS, Priddle J, Nedwell DB, Whitehouse MJ, Ellis-Evans JC, Deubert C, Connelly DP (2001) Regulation by low temperature of phytoplankton growth and nutrient uptake in the Southern Ocean. Mar Ecol Prog Ser 219:51-64

Reiss CS, Cossio AM, Loeb V, Demer DA (2008) Variations in the biomass of Antarctic krill (Euphausia superba) around the South Shetland Islands, 1996-2006. ICES J Mar Sci 65:497-508

Schlitzer R (2002) Carbon export fluxes in the Southern Ocean: results from inverse modeling and comparison with satellite-based estimates. Deep-Sea Res II 49:1623-1644

Schmidt K, Atkinson A, Petzke KJ, Voss M, Pond DW (2006) Protozoans as a food source for Antarctic krill, Euphausia superba: complementary insights from stomach content, fatty acids, and stable isotopes. Limnol Oceanogr 51: $2409-2427$

Schnack SB (1985) Feeding by Euphausia superba and copepod species in response to varying concentrations of phytoplankton. In: Siegfried WR, Condy PR (eds) Antarctic nutrient cycles and food webs. Springer-Verlag, Berlin, p 311-323

Shreeve RS, Ward P, Whitehouse MJ (2002) Copepod growth and development around South Georgia: relationships with temperature, food and krill. Mar Ecol Prog Ser 233: 169-183

Shreeve RS, Tarling GA, Atkinson A, Ward P, Goss C, Watkins J (2005) Relative production of Calanoides acutus (Copepoda: Calanoida) and Euphausia superba (Antarctic krill) at South Georgia, and its implications at wider scales. Mar Ecol Prog Ser 298:229-239

Smetacek V, Assmy P, Henjes J (2004) The role of grazing in structuring Southern Ocean pelagic ecosystems and biogeochemical cycles. Antarct Sci 16:541-558

Smith WO Jr, Lancelot C (2004) Bottom-up versus top-down control in phytoplankton of the Southern Ocean. Antarct Sci 16:531-539

Straile D (1997) Gross growth efficiencies of protozoan and metazoan zooplankton and their dependence on food concentration, predator-prey weight ratio, and taxonomic group. Limnol Oceanogr 42:1375-1385

Trathan PN, Brierley AS, Brandon MA, Bone DG and others

Editorial responsibility: Graham Savidge,

Portaferry, UK
(2003) Oceanographic variability and changes in Antarctic krill (Euphausia superba) abundance at South Georgia. Fish Oceanogr 12:569-583

Urban-Rich J, Dagg M, Peterson J (2001) Copepod grazing impact on phytoplankton in the Pacific sector of the Antarctic Polar Front. Deep-Sea Res II 48:4223-4246

- Voronina NM (1998) Comparative abundance and distribution of major filter-feeders in the Antarctic pelagic zone. J Mar Syst 17:375-390

Ward P, Whitehouse MJ, Meredith MP, Murphy EJ and others (2002) The Southern Antarctic Circumpolar Current Front: physical and biological coupling at South Georgia. DeepSea Res I 49:2183-2202

> Ward P, Shreeve R, Whitehouse M, Korb B and others (2005) Phyto- and zooplankton community structure and production around South Georgia (Southern Ocean) during summer 2001/02. Deep-Sea Res I 52:421-441

- Watkins JL, Brierley AS (1996) A post-processing technique to remove background noise from echo integration data. ICES J Mar Sci 53:339-344

Weber LH, El-Sayed SZ (1985) Spatial variability of phytoplankton and the distribution and abundance of krill in the Indian sector of the Southern Ocean In: Siegfried WR, Condy PR, Laws RM (eds) Antarctic nutrient cycles and food webs. Springer-Verlag, Berlin, p 284-293

Weber LH, El-Sayed SZ, Hampton I (1986) The variance spectra of phytoplankton, krill and water temperature in the Antarctic Ocean south of Africa. Deep-Sea Res 33: 1327-1343

Whitehouse MJ (1997) Automated seawater nutrient chemistry. British Antarctic Survey, Cambridge

- Whitehouse MJ, Priddle J, Symon C (1996) Seasonal and annual change in seawater temperature, salinity, nutrient and chlorophyll a distributions around South Georgia, South Atlantic. Deep-Sea Res I 43:425-443

Whitehouse MJ, Priddle J, Brandon MA (2000) Chlorophyll/ nutrient characteristics in the water masses to the north of South Georgia, Southern Ocean. Polar Biol 23:373-382

> Whitehouse MJ, Korb RE, Atkinson A, Thorpe SE, Gordon M (2008) Formation, transport and decay of an intense phytoplankton bloom within the high-nutrient low-chlorophyll belt of the Southern Ocean. J Mar Syst 70:150-167

- Woodward EMS, Rees AP, Stephens JA (1999) The influence of the south-west monsoon upon the nutrient biogeochemistry of the Arabian Sea. Deep-Sea Res II 46: $571-591$

Submitted: December 5, 2008; Accepted: August 27, 2009

Proofs received from author(s): October 14, 2009 